\title{
International study into the use of intermittent hormone therapy in the treatment of carcinoma of the prostate (ISICAP), a meta-analysis of 1446 patients.
}

Shaw $\mathrm{G}^{1}$, Wilson $\mathrm{P}^{1}$, Cuzick $\mathrm{J}^{2}$, Prowse $\mathrm{D}^{1}$, Oliver RTD

${ }^{1}$ St Bartholomew's Hospital, London, UK

${ }^{2}$ Cancer Research UK, London, UK

We are grateful to the following people for providing patient data for the collated dataset and for their input into discussion, analysis and review of the manuscript:

Goldenberg SL The Prostate Centre at VGH, Vancouver, Canada

Spry N, University of Western Australia, Perth, Australia

Prapotnich D, Dept of Urology, Université René Descartes, Faculté des Saints Pères,

Paris, France

Forman J, Gerhenson Radiation Oncology Center of the Barbara Ann Karmanos

Cancer Institute, Wayne State University, Detroit, Michigan, USA

Scholz MC and Strum S, The Prostate Cancer Research Institute, L.A., California, USA

Albrecht W, Dept of Urology, Rudolfstiiftung, Juchgasse 25, Vienna, Austria

We are grateful to the following for providing patient data for the collated dataset:

Small EJ, University of California, San Francisco, School of Medicine, San Francisco, California, USA

Zerbib M, Department of Urology, CHU Cochin, Paris, France

Malone S, Department of Radiation Oncology, Ottawa Regional Cancer Centre, Canada

\section{Corresponding author:}

Mr Greg Shaw BSc MRCSEng

Clinical Research Fellow in Prostate Cancer,

Department of Medical Oncology,

St Bartholomews Hospital,

West Smithfield,

London

EC1A 7BE

Tel 02076018522

Email: gregshaw@doctors.org.uk 


\section{Abstract}

Introduction: Intermittent hormone therapy (IHT) was developed to reduce morbidity of treating metastatic prostate cancer. Increasingly it is seen as an alternative to "watchful waiting" in those who the need for radical treatment is uncertain. Here pooled phase 2 data is reviewed to see if this apparent efficacy is supported. Preliminary comparisons between the different IHT regimens used are made. Models predicting success of treatment are generated. The use of time off treatment to indicate treatment success is examined. Possible future trials using this endpoint are suggested.

Methods: Data was collated on 1446 patients with adequate data, from 10 phase 2 studies with more than 50 cases, identified through Pubmed.

Results: Patients with localised disease achieved 90\% 5yr survival, 29\% off hormone therapy for over 2 years and $10 \%$ hormone resistant in 5 years. This compared to $86 \%$, $33 \%$ and $17 \%$ respectively for biochemical recurrence in patients after radical treatment and $68 \%, 16 \%$ and $41 \%$ for metastatic disease.

Univariate and multivariate Cox proportional hazard modeling demonstrated that initial PSA and PSA nadir were important predictors of time off therapy. $40 \%$ of patients with localized disease with a pre-treatment PSA less than 10 were off treatment at 2 years after $<4$ months therapy.

Conclusion: Initial PSA and PSA nadir enable definition of prostate cancer patients in whom it may be safe to avoid radical therapy. This strategy should be tested in future trials against watchful waiting and radical therapy. 


\section{Introduction}

It has been said of patients with prostate cancer that those who are curable by radical prostatectomy don't need to be cured, and those that need to be cured, can't be cured[1]. This view first became established in the light of results from the two randomized Veterans Administration Collaborative Group (VACURG) studies [2]. These were placebo-controlled trials examining the role of endocrine treatment. They were initiated following a retrospective analysis of Nesbit's personal series in the 1950s who questioned the value of early treatment [3]. Today 4516 patients have been recruited into 5 randomized trials [4-8] and a benefit to immediate treatment is still contentious. On close examination, the VACURG trials provide some evidence in favor of immediate treatment. The first study with 2000 patients randomized was the largest and because it used high dose stilboestrol (5mg), had excess cardiac deaths and showed no advantage to early treatment because of these excess deaths. This study, though never published formally, led to an attitude of benign neglect developing over the use of early hormone treatment. This was despite the second VACURG study (508 patients) which used a less toxic dose of stilboestrol (1mg) and demonstrated $9 \%$ less deaths with immediate treatment. The three subsequent studies have recruited a total of 2107 patients and have shown a consistent $5 \%$ less deaths from immediate treatment, though in only the last study [9] was the difference statistically significant. Even in this most recent study, the authors conclude that deferring androgen ablation therapy was probably still the better option. This was because a substantial number of patients were spared the burden of continuous endocrine treatment. These were patients who would be expected to remain asymptomatic and not die of prostate cancer.

Recently Intermittent hormone therapy (IHT, also Intermittent Androgen Suppression and Intermittent Androgen Deprivation), initially introduced to reduce morbidity of 
treating metastatic disease, has emerged as an alternative better tolerated treatment option to "watchful waiting" in those who the need for radical treatment is uncertain. A 766 case phase three trial comparing three months of IHT with continuous therapy demonstrated that IHT, as well as producing equivalent overall survival, allowed $29 \%$ of those randomized to the IHT arm to remain off treatment for 3 years [10;11].

The aims of this study are:

- To compare results of smaller phase two studies with the randomised trial.

- To develop models predicting success in IHT.

- To describe features of IHT protocols conferring success

- To evaluate the use of time off treatment as a surrogate predictor of survival for use in future IHT trials.

\section{Methods}

A Pubmed search was undertaken with keywords intermittent hormone/androgen ablation, the references from the papers found were checked and authors were consulted as to other sources of data. Ten groups with data pertaining to the use of IHT $(n>50)$ were identified [12-21]. Table 1 shows the origin and basic characteristics of the patients in each study as well as the IHT protocol characteristics. Individual patient data was collected from the authors and collated into a database of 1498 patients. Of these, 1446 had adequate data for inclusion in our analysis. All patients were hormone naïve prior to starting $\mathrm{IHT}$.

Patient data was grouped into:

Group 1) Localized disease (NOM0) treated primarily with IHT

Group 2) PSA recurrence after failed curative attempts with radiotherapy, prostatectomy or both, and

Group 3) Metastatic disease treated with IHT. 
Data was analyzed using Stata Intercooled 8.0. All durations are the length of time after starting hormone therapy. Day 1 is the first day that hormones were given. Kaplan Meier Survival analysis was undertaken. Univariate and multivariate Cox proportional hazard models were developed for each of the three groups. A forward stepwise procedure was used to develop the multivariate models in Stat 8.0. The variables available for addition to the model were initial PSA, type of hormone treatment, duration of treatment, PSA nadir, age, T stage, Gleason grade, previous treatment, restart PSA threshold and metastatic status. The results of the univariate analysis were used to select which variable should be added to the model (see appendices 1 and 2 for detailed results of univariate analysis). The variables were dichotomized for further analysis about clinically relevant thresholds. The change in $\mathrm{chi}^{2}$ in the multivariate results (figure 1 and supplementary table- appendix 3 ) indicates the proportion of variability in outcome explained by the variable. A large change in chi ${ }^{2}$ indicates that a variable is important in predicting the particular outcome.

Success of treatment was measured according to three factors:

1. Time spent in clinical remission and off treatment after initial period of androgen deprivation.

2. Time to AIPC (AIPC is defined as two successively rising PSA measurements or clinical progression despite hormone therapy.

3. Overall survival (OS) 


\section{Results}

Data was collected on 1446 patients. Median age was 71 years. 366 patients had proven nodal or metastatic disease at the time of starting IHT. Of the remaining 1080 with no known metastatic disease, for 517 patients this was the primary treatment. The remaining 563 were treated for recurrent disease after failed Radical Prostatectomy $(\mathrm{RP})$ radiotherapy $(\mathrm{RT})$ or both.

Median number of cycles was 2. Median follow up for all patients was 39 months. Maximum follow up was 197 months. Median time off treatment for all patients was 15.4 months. 181 patients developed AIPC. 218 died.

Overall 29 percent of patients with localized disease were off treatment 2 years after the initial period of hormone ablation was complete, $90 \%$ were alive at 5 years and $10 \%$ had become androgen independent (Table 2). This compares to $33 \%, 86 \%$ and $17 \%$ in the biochemical recurrence group 2 and 16\%, 68\% and $41 \%$ in group 3 . Table 3 shows a summary of the uni-variate analysis (see appendix supplementary tables $6 \& 7$ for details). The results of the multivariate modeling are shown in figure 1. Table 4 demonstrates the association between duration of remission and the other outcome measures. Table 5 shows that the duration of remission is not dependent on the level to which the PSA is allowed to rise before treatment in restarted.

\section{Discussion}

From the time of the original observation on the use of hormonal manipulation as a treatment for prostate cancer[22] and the development of means of medical castration there has been controversy over when and for how long medical treatment should be administered for. This first emerged in a publication when Nesbit retrospectively reviewed a series with early and late hormonal treatment [23]. This led Byar to set up The VACURG [24-26] studies demonstrated the excess deaths with high dose 
oestrogen that negated any benefit from therapy and laid the ground for 30 years of negative attitude towards early endocrine therapy. The concerns about early use of continuous therapy persisted throughout the introduction of the LHRH analogues. The concerns about early use continued throughout the introduction of maximum androgen blockade (MAB) [27].

The recent study by Studer et al [28] has produced evidence which might reverse this negative attitude. However, in demonstrating a minor benefit of early treatment he still concluded that this might not be adequate to justify routine early use of continuous hormone ablation. This was because of the advanced age of the patients, their significant co-existent morbidities and most importantly, the severity of the chronic morbidity associated with continuous hormone therapy. These are well described and include anaemia, osteoporosis, impotence, cognitive functional effects, gynaecomastia, muscle atrophy, depression, dyslipidaemias and generalized lethargy [29-31]. This is the background to modern standards of care using endocrine therapy in prostate cancer. Continuous hormone therapy is the standard of care only in patients with metastatic and poor risk locally advanced disease.

It is now nearly 20 years since the first attempts were made to diminish side effects of continuous therapy by giving pulsed endocrine treatments for long enough to normalize symptoms and signs of disease activity. The first series published by Klotz et al described the use pulsed stilboestrol therapy for advanced prostate cancer with improved side effects [32]. This prompted further clinical and laboratory experiments to try and establish a scientific rationale for this type of treatment. 
Work by Bruchovsky et al and Sato et al with mice models demonstrated that by castrating the animals and administering pulses of testosterone the onset of androgen independence was delayed and those receiving pulses of testosterone survived longer. [33].

During the past decade this preclinical evidence has prompted several phase 2 clinical studies of intermittent hormone therapy, though as table 1 shows, there has been considerable variation in approach. Initially treatment was with MAB for 6-9 months depending on the time to get PSA below 4. With the reports casting doubt on the scientific rationale for MAB, some groups used LHRH monotherapy with no immediate worsening of results. Reports of excess non-cancer deaths after continuous antiandrogen monotherapy prompted one group to explore intermittent therapy with this agent [35] even though the relatively elevated testosterone levels induced by these agents might have been expected to accelerate re-growth of cancer in such patients. Surprisingly this did not happen, though the authors did seem to report a higher rate of progression to androgen resistance.

The results that have emerged from one of the three currently ongoing phase three clinical trials $[11 ; 36]$ generated the impetus to set up this meta-analysis. This trial, by the Southern European Uro-Oncology group (SEUG) which used LHRH and the antiandrogen cyproterone acetate to treat metastatic and locally advanced disease patients, is the largest that has been recruited to date. With 626 patients they showed equivalence between continuous and intermittent treatment for disease progression and prostate cancer specific deaths with 8 years follow up. Two observations of considerable importance emerged. Firstly the authors had only used 3 months of 
therapy before stopping treatment in the IHT arm and secondly they were able to demonstrate improved outcome in those achieving PSA less than 1.

The results of our univariate and multivariate modeling are in agreement with the findings of the SEUG trial and confirm that stopping treatment in patients that achieve a good PSA response at 3 months is not deleterious to survival. Initial PSA and PSA nadir are consistent independent predictors of duration of remission. This observation does not of course exclude the longstanding critique of $\mathrm{IHT}$, i.e. that the time off treatment is entirely due to the slowness of recovery of circulating testosterone. Studies have demonstrated that $90 \%$ of patients who have been treated with 3 months LHRH recover a normal testosterone within 18 weeks[37]. In the SEUG trial the majority of sexually active men in the intermittent arm recovered potency. These factors suggest that persistent low testosterone is not the explanation of the prolonged remission period.

That monotherapy with anti-androgen alone was significantly less effective than Maximal androgen blockade or LHRH alone in groups 1 and 3 suggests that for the time being MAB or LHRH alone should be the standard for IHT trials. However, the surprising finding of increased survival in patients on anti-androgen monotherapy, might justify the use of these better tolerated drugs in specific subsets of prostate cancer patients, particularly those with biochemical recurrence after radiotherapy/prostatectomy [38].

Using our dataset multivariate models which predicted time off treatment in all patient groups to a highly significant degree were generated. A model to predict the development of AIPC and overall survival could only be generated for group 3 (those with metastatic disease) as development of AIPC and death were too rare in the other 
groups. This indicates the long follow up required to demonstrate differences in AIPC/death in this patient group.

Table 4 demonstrates the association between time off treatment in the first cycle and time to develop AIPC $(p<0.0001)$ and with time to death (not disease specific $p<0.0001)$. Those with off periods of greater than 2 or 3 years or in the first cycle survive longer and develop androgen independent prostate cancer later than those with shorter duration off treatment. This might be used as an early indicator of treatment success in trials and might be used to demonstrate the effectiveness of different treatment protocols (with more or less patients staying off treatment for at least two or three years depending on treatment efficacy) prior to demonstration of a difference in the rate of androgen independence or death for which duration of follow up would be extensive.

One concern about use of time off treatment as an indicator of treatment success for clinical trials, is that PSA rise being time dependant, it might be that the duration of a remission period is only dependant upon the level to which PSA is allowed to rise before retreatment. In table 5 it is demonstrated that this is not so. No significant difference was seen between the duration of preceding remission periods when patients were grouped according to the PSA at which their treatment was restarted.

The collated dataset lends itself to analysis to evaluate which features of an IHT protocol render it most successful (within the bounds of those protocols already in use). The results will be useful in designing clinical trials examining the optimal use of IHT. 
In order to better understand the biology of prostate cancer with hormone treatment and to evaluate the safety and efficacy of the variety of IHT protocols that are included in this study randomized controlled clinical trials are required.

A recent Editorial in the Journal of Urology describes how prostate cancer is overtreated at present [39]. The observations made in this meta-analysis taken with the SEUG trial data provide support for identifying cases not requiring radical treatment and as exploring the use of 3 months MAB as an alternate to watchful waiting.

\section{Conclusions}

The increasing evidence from randomized trials that $\mathrm{IHT}$ is safe is supported by this meta-analysis. Our data suggest that it is possible to curtail treatment duration to 3 months (in all patients except those with metastatic disease). A randomized controlled trial to see if this bears out prospectively is indicated. Given the low toxicity of such a course of treatment the next priority for a trial must be in patients not willing to accept the anaemia, bone thinning, impotence and changes in cognitive function associated with continuous therapy, ie those for whom watchful waiting would be suitable. Outcome should include assessment of side effects. Testosterone levels should be monitored.

\section{Limitations}

Medication type has been grouped despite acknowledging differences in different individual drugs and doses used. Testosterone levels are not analysed. 


\section{Acknowledgements}

Work undertaken with support from the Orchid Cancer Appeal.

Competing interests- None

The Authors thank the European Organization for Research and Treatment of Cancer for permission to use data from EORTC trial 30954 for this research.

The ISICAP group met in March 2005 and March 2006 to review preliminary analysis and drafts.

References

1. Whitmore, W. F., Jr. Natural history of low-stage prostatic cancer and the impact of early detection. Urol. Clin. North Am. 17:689-697, 1990.

2. Byar, D. P. VACURG studies of conservative treatment \& VACURG studies of post-prostatectomy survival. Scand. J. Urol. Nephrol. Supp/ 55:99-102-113-116, 1980.

3. NESBIT, R. M. and BAUM, W. C. Endocrine control of prostatic carcinoma; clinical and statistical survey of 1,818 cases. J. Am. Med. Assoc. 143:1317-1320, 1950.

4. Abrahamsson, P. A., Anderson, J., Boccon-Gibod, L., Schulman, C., Studer, U. E., and Wirth, M. Risks and benefits of hormonal manipulation as monotherapy or adjuvant treatment in localised prostate cancer. Eur. Urol. 48:900-905, 2005.

5. Arduino, L. J., Bailar, J. C., and Becker, L. E. Carcinoma of the prostate:Treatment comparisons. J.Urol. 98, 516-522. 1-1-1967.

Ref Type: Generic

6. Kirk D. Immediate versus deferred hormone treatment for prostate cancer: how safe is androgen deprivation? BJU.Int. 86[(supp 3)], S220. 1-10-2000. 
Ref Type: Generic

7. Studer, U. E., Hauri, D., Hanselmann, S., Chollet, D., Leisinger, H. J., Gasser, T., Senn, E., Trinkler, F. B., Tscholl, R. M., Thalmann, G. N., and Dietrich, D. Immediate versus deferred hormonal treatment for patients with prostate cancer who are not suitable for curative local treatment: results of the randomized trial SAKK 08/88. J. Clin. Oncol. 22:4109-4118, 2004.

8. THE MEDICAL RESEARCH COUNCIL PROSTATE CANCER WORKING PARTY INVESTIGATORS GROUP. Immediate versus deferred treatment for advanced prostatic cancer: initial results of the Medical Research Council trial. BJU International 79[2], 235. 1-2-1997.

Ref Type: Generic

9. Abrahamsson, P. A., Anderson, J., Boccon-Gibod, L., Schulman, C., Studer, U. E., and Wirth, M. Risks and benefits of hormonal manipulation as monotherapy or adjuvant treatment in localised prostate cancer. Eur. Urol. 48:900-905, 2005.

10. Calais Da Silva F and Bono A. Phase III study of Intermittent MAB versus continuous MAB. International co-operative study (abstract). Whelan P, Brausi M, Queimadelos M, Portilho J, and Kirkali Z. J.Urol. 173[(4) supp], 309. 1-4-0005.

Ref Type: Generic

11. Calais Da Silva F. SEUG Intermittent Hormone Therapy Trial 9901. Unpublished data, Personal communication . 2005.

Ref Type: Generic

12. Albrecht, W., Collette, L., Fava, C., Kariakine, O. B., Whelan, P., Studer, U. E., De Reijke, T. M., Kil, P. J., and Rea, L. A. Intermittent maximal androgen blockade in 
patients with metastatic prostate cancer: an EORTC feasibility study. Eur. Urol. 44:505-511, 2003.

13. Crook, J. M., Szumacher, E., Malone, S., Huan, S., and Segal, R. Intermittent androgen suppression in the management of prostate cancer. Urology 53:530-534, 1999.

14. De La Taille, A., Zerbib, M., Conquy, S., Amsellem-Ouazana, D., Thiounn, N., Flam, T. A., and Debre, B. Intermittent androgen suppression in patients with prostate cancer. BJU. Int. 91:18-22, 2003.

15. Goldenberg, S. L., Bruchovsky, N., Gleave, M. E., Sullivan, L. D., and Akakura, K. Intermittent androgen suppression in the treatment of prostate cancer: a preliminary report. Urology 45:839-844, 1995.

16. Grossfeld, G. D., Small, E. J., and Carroll, P. R. Intermittent androgen deprivation for clinically localized prostate cancer: initial experience. Urology 51:137-144, 1998.

17. Lane, T. M., Ansell, W., Farrugia, D., Wilson, P., Williams, G., Chinegwundoh, F., Philp, T., Hines, J., and Oliver, R. T. Long-term outcomes in patients with prostate cancer managed with intermittent androgen suppression. Urol. Int. 73:117-122, 2004.

18. Leibowitz, R. L. and Tucker, S. J. Treatment of localized prostate cancer with intermittent triple androgen blockade: preliminary results in 110 consecutive patients. Oncologist. 6:177-182, 2001. 
19. Prapotnich, D., Fizazi, K., Escudier, B., Mombet, A., Cathala, N., and Vallancien, G. A 10-year clinical experience with intermittent hormonal therapy for prostate cancer. Eur. Urol. 43:233-239, 2003.

20. Strum, S. B., Scholz, M. C., and McDermed, J. E. Intermittent androgen deprivation in prostate cancer patients: factors predictive of prolonged time off therapy. Oncologist. 5:45-52, 2000.

21. Youssef, E., Tekyi-Mensah, S., Hart, K., Bolton, S., and Forman, J. Intermittent androgen deprivation for patients with recurrent/metastatic prostate cancer. Am. J. Clin. Oncol. 26:e119-e123, 2003.

22. Mouraviev, V. and Gleave, M. E. A meaningful legacy: urologists as Nobel Prize laureates. Can. J. Urol. 10:1737-1742, 2003.

23. NESBIT, R. M. and BAUM, W. C. Endocrine control of prostatic carcinoma; clinical and statistical survey of 1,818 cases. J. Am. Med. Assoc. 143:1317-1320, 1950.

24. Byar, D. P. VACURG studies of conservative treatment. Scand. J. Urol. Nephrol. Supp/ 55:99-102, 1980.

25. Byar, D. P. VACURG studies of post-prostatectomy survival 88. Scand. J. Urol. Nephrol. Supp/ 55:113-116, 1980.

26. Byar, D. P. and Corle, D. K. VACURG randomised trial of radical prostatectomy for stages I and II prostatic cancer. Veterans Administration Cooperative Urological Research Group

86. Urology 17:7-11, 1981. 
27. Maximum androgen blockade in advanced prostate cancer: an overview of the randomised trials. Prostate Cancer Trialists' Collaborative Group. Lancet 355:1491-1498, 2000.

28. Studer, U. E., Hauri, D., Hanselmann, S., Chollet, D., Leisinger, H. J., Gasser, T., Senn, E., Trinkler, F. B., Tscholl, R. M., Thalmann, G. N., and Dietrich, D. Immediate versus deferred hormonal treatment for patients with prostate cancer who are not suitable for curative local treatment: results of the randomized trial SAKK 08/88. J. Clin. Oncol. 22:4109-4118, 2004.

29. Berruti, A., Tucci, M., Terrone, C., Gorzegno, G., Scarpa, R. M., Angeli, A., and Dogliotti, L. Background to and management of treatment-related bone loss in prostate cancer. Drugs Aging 19:899-910, 2002.

30. Salminen, E. K., Portin, R. I., Koskinen, A., Helenius, H., and Nurmi, M. Associations between serum testosterone fall and cognitive function in prostate cancer patients. Clin. Cancer Res. 10:7575-7582, 2004.

31. Strum, S. B., Scholz, M. C., and McDermed, J. E. The Androgen Deprivation Syndrome: the incedence and severity in prostate cancer patients receiving hormone blockade. Proc Amer Soc Clin Onc 17, 316a. 1998.

Ref Type: Generic

32. Klotz, L. H., Herr, H. W., Morse, M. J., and Whitmore, W. F., Jr. Intermittent endocrine therapy for advanced prostate cancer. Cancer 58:2546-2550, 1986.

33. Bruchovsky, N., Klotz, L. H., Sadar, M., Crook, J. M., Hoffart, D., Godwin, L., Warkentin, M., Gleave, M. E., and Goldenberg, S. L. Intermittent androgen 
suppression for prostate cancer: Canadian Prospective Trial and related observations. Mol. Urol. 4:191-199, 2000.

34. Sato, N., Gleave, M. E., Bruchovsky, N., Rennie, P. S., Goldenberg, S. L., Lange, P. H., and Sullivan, L. D. Intermittent androgen suppression delays progression to androgen-independent regulation of prostate-specific antigen gene in the LNCaP prostate tumour model. J. Steroid Biochem. Mol. Biol. 58:139-146, 1996.

35. Peyromaure, M., Delongchamps, N. B., Debre, B., and Zerbib, M. Intermittent androgen deprivation for biologic recurrence after radical prostatectomy: long-term experience. Urology 65:724-729, 2005.

36. Calais Da Silva F and Bono A. Phase III study of Intermittent MAB versus continuous MAB. International co-operative study (abstract). Whelan P, Brausi M, Queimadelos M, Portilho J, and Kirkali Z. J.Urol. 173[(4) supp], 309. 1-4-0005.

Ref Type: Generic

37. Gulley, J. L., Figg, W. D., Steinberg, S. M., Carter, J., Sartor, O., Higano, C. S., Petrylak, D. P., Chatta, G., Hussain, M. H., and Dahut, W. L. A prospective analysis of the time to normalization of serum androgens following 6 months of androgen deprivation therapy in patients on a randomized phase III clinical trial using limited hormonal therapy. J. Urol. 173:1567-1571, 2005.

38. Peyromaure, M., Delongchamps, N. B., Debre, B., and Zerbib, M. Intermittent androgen deprivation for biologic recurrence after radical prostatectomy: long-term experience. Urology 65:724-729, 2005.

39. Carroll, P. R. Early stage prostate cancer--do we have a problem with overdetection, overtreatment or both? J. Urol. 173:1061-1062, 2005. 
40. Youssef, E., Tekyi-Mensah, S., Hart, K., Bolton, S., and Forman, J. Intermittent androgen deprivation for patients with recurrent/metastatic prostate cancer. Am. J. Clin. Oncol. 26:e119-e123, 2003.

41. Crook, J. M., Szumacher, E., Malone, S., Huan, S., and Segal, R. Intermittent androgen suppression in the management of prostate cancer. Urology 53:530-534, 1999.

42. Grossfeld, G. D., Small, E. J., and Carroll, P. R. Intermittent androgen deprivation for clinically localized prostate cancer: initial experience. Urology 51:137-144, 1998.

43. De La, T. A., Zerbib, M., Conquy, S., Amsellem-Ouazana, D., Thiounn, N., Flam, T. A., and Debre, B. Intermittent androgen suppression in patients with prostate cancer. BJU. Int. 91:18-22, 2003.

44. Goldenberg, S. L., Bruchovsky, N., Gleave, M. E., Sullivan, L. D., and Akakura, K. Intermittent androgen suppression in the treatment of prostate cancer: a preliminary report. Urology 45:839-844, 1995.

45. Prapotnich, D., Fizazi, K., Escudier, B., Mombet, A., Cathala, N., and Vallancien, G. A 10-year clinical experience with intermittent hormonal therapy for prostate cancer. Eur. Urol. 43:233-239, 2003.

46. Albrecht, W., Collette, L., Fava, C., Kariakine, O. B., Whelan, P., Studer, U. E., De Reijke, T. M., Kil, P. J., and Rea, L. A. Intermittent maximal androgen blockade in patients with metastatic prostate cancer: an EORTC feasibility study. Eur. Urol. 44:505-511, 2003. 
Table 1.

\begin{tabular}{|c|c|c|c|c|c|c|c|}
\hline $\begin{array}{l}\text { Reference } \\
\text { author }\end{array}$ & Origin & $\mathbf{N}$ & $\begin{array}{l}\text { Type of } \\
\text { disease }\end{array}$ & $\begin{array}{l}\text { Type of } \\
\text { treatment }\end{array}$ & $\begin{array}{l}\text { PSA nadir for } \\
\text { adequate } \\
\text { response }\end{array}$ & $\begin{array}{l}\text { Restart } \\
\text { PSA }\end{array}$ & $\begin{array}{l}\% \text { off at } 2 \\
\text { years }\end{array}$ \\
\hline Strum [20] & $\begin{array}{l}\text { California, } \\
\text { USA }\end{array}$ & 53 & $L \& A$ & MAB & $<0.05$ & $>5$ & 13 \\
\hline $\begin{array}{l}\text { Forman } \\
{[17 ; 40]}\end{array}$ & $\begin{array}{l}\text { Michigan, } \\
\text { USA }\end{array}$ & 104 & $L, R \& A$ & $\begin{array}{l}\text { MAB / } \\
\text { mono }\end{array}$ & $<4$ & $>10$ & 39 \\
\hline Malone [41] & $\begin{array}{l}\text { Ottawa, } \\
\text { Canada }\end{array}$ & 86 & $\mathrm{~L}, \mathrm{R} \& \mathrm{~A}$ & $\begin{array}{l}\text { MAB / } \\
\text { mono }\end{array}$ & $<4$ & $>10$ & 20 \\
\hline Small [42] & $\begin{array}{l}\text { San } \\
\text { Francisco, } \\
\text { USA }\end{array}$ & 53 & L\& \& & $\begin{array}{l}\text { MAB / } \\
\text { mono }\end{array}$ & $\begin{array}{l}<4 \text { if no prev } \\
\text { Rx }<0.1 \text { post } \\
\text { RT/RP }\end{array}$ & $\begin{array}{l}>10 \\
\text { Or }>50 \% \\
\text { baseline }\end{array}$ & 36 \\
\hline Zerbib [43] & $\begin{array}{l}\text { Paris, } \\
\text { France }\end{array}$ & 160 & $L, R \& A$ & $\begin{array}{l}\text { MAB I } \\
\text { mono }\end{array}$ & $\begin{array}{l}<1 \text { no prev } \mathrm{Rx} \\
<0.05 \text { post } \mathrm{RP} \\
<4 \text { post } \mathrm{RT}\end{array}$ & $\begin{array}{l}>10 \\
>4 \text { post } \\
\text { RP }\end{array}$ & 11 \\
\hline $\begin{array}{l}\text { Goldenberg } \\
\text { [44] }\end{array}$ & $\begin{array}{l}\text { Vancouver, } \\
\text { Canada }\end{array}$ & 101 & $L, R \& A$ & $\begin{array}{l}\text { MAB / } \\
\text { mono }\end{array}$ & $<2$ & $\begin{array}{l}>10 \\
>4 \text { post } \\
\text { RP }\end{array}$ & 17 \\
\hline Spry & $\begin{array}{l}\text { Perth, } \\
\text { Australia }\end{array}$ & 239 & $L, R \& A$ & MAB & $\begin{array}{l}\text { Variable- all } 9 \\
\text { months MAB }\end{array}$ & $>20$ & 31 \\
\hline Oliver [17] & $\begin{array}{l}\text { London } \\
\text { U.K. }\end{array}$ & 125 & $L, R \& A$ & $\begin{array}{l}\text { MAB / } \\
\text { mono }\end{array}$ & $<4$ & $>20$ & 30 \\
\hline $\begin{array}{l}\text { Prapotnich } \\
\text { [45] }\end{array}$ & $\begin{array}{l}\text { Paris, } \\
\text { France }\end{array}$ & 411 & $L, R \& A$ & MAB & $<4$ & $>20$ & 40 \\
\hline $\begin{array}{l}\text { Albrecht } \\
\text { [46] }\end{array}$ & Europe & 114 & A & MAB & $\begin{array}{l}<20 \text { or } \\
<20 \% \text { initial }\end{array}$ & $\begin{array}{l}>20 \text { or } \\
>1.5^{*} \text { nadir }\end{array}$ & $\begin{array}{l}6 \\
\text { (at } 1 \text { year) }\end{array}$ \\
\hline
\end{tabular}


Table 2.

\begin{tabular}{|c|c|c|c|}
\hline & $\begin{array}{c}\text { Group 1 Localized } \\
\text { disease (n=517) }\end{array}$ & $\begin{array}{c}\text { Group 2 } \\
\text { Biochemical } \\
\text { recurrence (NOM0) } \\
(\mathrm{n}=563)\end{array}$ & $\begin{array}{c}\text { Group 3 } \\
\text { Metastatic disease } \\
(\mathrm{n}=366)\end{array}$ \\
\hline $\begin{array}{c}\text { Overall survival at 5 years } \\
\text { Patients off treatment at 2 } \\
\text { years }\end{array}$ & $90 \%$ & $86 \%$ & $68 \%$ \\
\hline $\begin{array}{c}\text { Patients with AIPC at 5 } \\
\text { years }\end{array}$ & $10 \%$ & $33 \%$ & $16 \%$ \\
\hline
\end{tabular}


Table 3.

\begin{tabular}{|c|c|c|c|c|c|c|c|c|c|c|}
\hline & \multicolumn{3}{|c|}{ Time off treatment } & \multicolumn{3}{|c|}{ Androgen resistance } & \multicolumn{3}{|c|}{ Overall survival } \\
\hline & & Group 1 & Group 2 & Group 3 & Group 1 & Group 2 & Group 3 & Group 1 & Group 2 & Group 3 \\
\hline \multirow[t]{2}{*}{ T stage } & $1 / 2$ & - & - & - & - & - & - & - & - & - \\
\hline & $3 / 4$ & - & $1.48 * \star \star$ & - & - & - & - & $1.85 * \star$ & - & - \\
\hline \multirow[t]{3}{*}{ Initial PSA } & $<10$ & - & - & - & - & - & - & - & - & - \\
\hline & $10-75$ & $1.47^{\star \star}$ & $1.44^{\star \star \star}$ & $1.77^{\star \star}$ & $6.42^{\star \star \star}$ & 1.62 * & 5.52 ** & $2.7^{\star \star}$ & - & - \\
\hline & $>75$ & $1.41^{\star \star}$ & - & 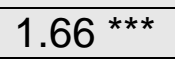 & $2.65 * \star$ & - & 3.26 ** & - & - &  \\
\hline \multirow[t]{2}{*}{ Grade } & $2-7$ & - & - & - & - & - & - & - & - & - \\
\hline & $8-10$ & - & 1.36 ** & - & - & - & - & - & - & - \\
\hline \multirow[t]{3}{*}{ PSA Nadir } & $<1$ & - & - & - & - & - & - & - & - & - \\
\hline & $1-2$ & 1.68 *** & - & - & - & - & 2.12 ** & - & - & 2.12 ** \\
\hline & $>2$ & - & $1.77^{\star \star \star}$ & $1.43^{\star \star \star}$ & - & - & - & - & - & - \\
\hline \multirow{3}{*}{$\begin{array}{l}\text { Type of } \\
\text { medication }\end{array}$} & MAB & - & - & - & - & - & - & - & - & - \\
\hline & $a / a$ & 2.14 * & 2.59 * & - & $3.78^{\star \star}$ & - & - & - & - & - \\
\hline & LHRH & - & - & - & 4.41 ** & - & - & - & - & - \\
\hline \multirow{3}{*}{$\begin{array}{l}\text { Duration on } \\
\text { treatment }\end{array}$} & $\leq 4$ months & - & - & - & - & - & - & - & - & 1.86 * \\
\hline & 4-8 months & - & - & - & 4.44 * & - & - & - & - & $2.83^{\star \star \star *}$ \\
\hline & $\geq 8$ months & - & - & - & $6.05^{* *}$ & - & - & - & - & - \\
\hline \multirow[t]{2}{*}{ Age } & $<65$ & - & 1.55 *** & - & - & - & - & - & - & - \\
\hline & $\geq 65$ & - & - & - & - & - & - & - & - & - \\
\hline \multirow{2}{*}{$\begin{array}{l}\text { PSA restart } \\
\text { threshold }\end{array}$} & $\leq 15$ & - & - & - & - & - & - & - & - & - \\
\hline & $>15$ & - & - & - & & - & 1.33 * & - & - & 1.65 * \\
\hline \multirow[t]{2}{*}{ Prev Rx } & None & - & - & - & - & - & - & - & - & - \\
\hline & RT \&/or RP & - & - & 2.2 *** & - & - & - & - & - & - \\
\hline
\end{tabular}


Figure $1 \mathrm{a}$

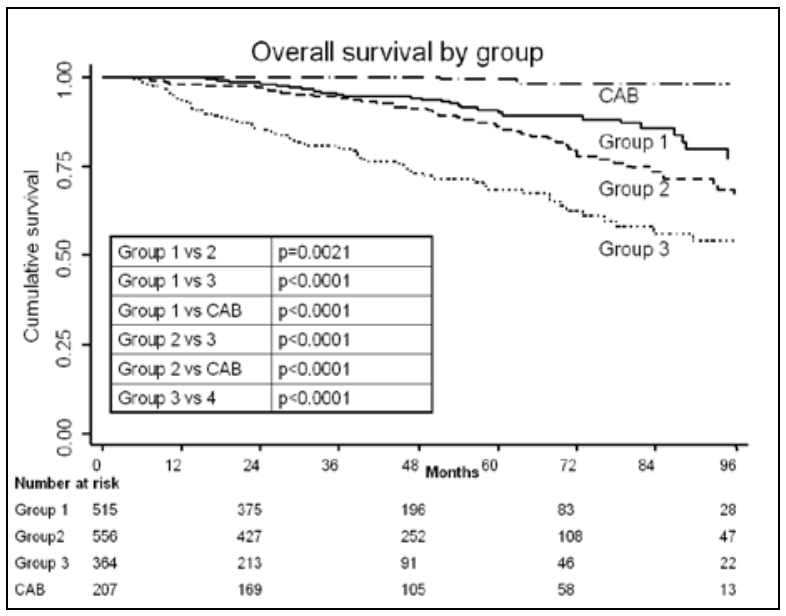

Figure $1 b$

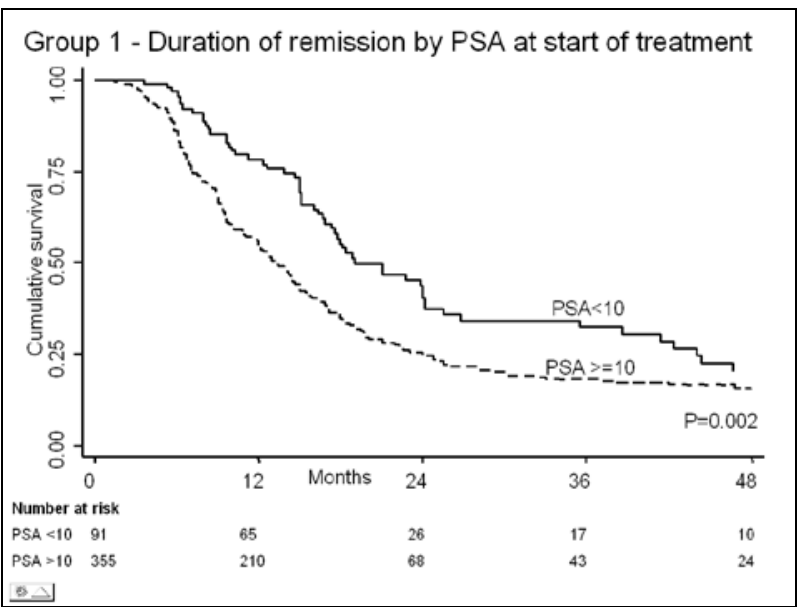


Figure 2.
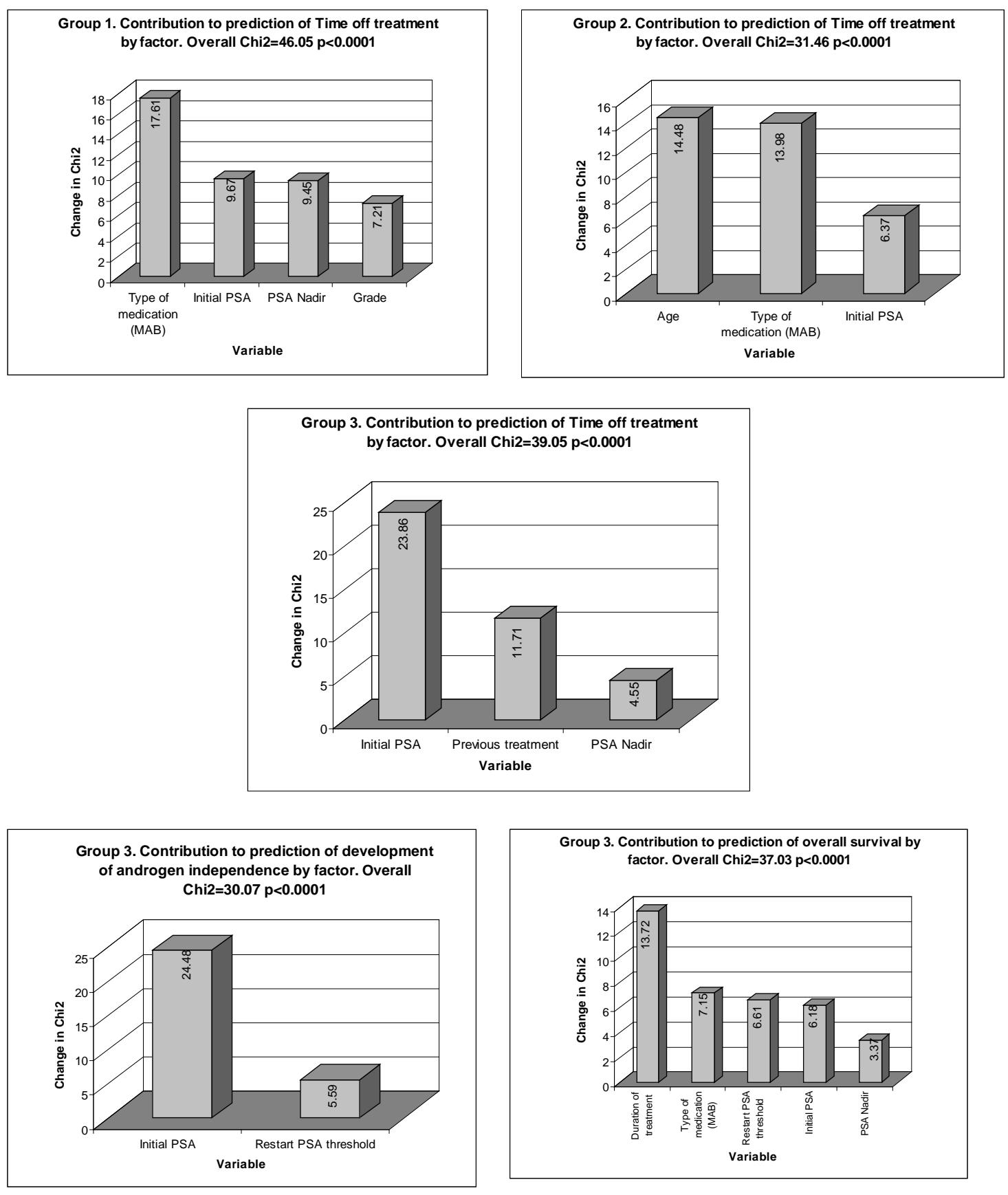
Table 4.

Excluding $<2$ years

\begin{tabular}{|c|c|c|c|c|}
\hline \multirow{2}{*}{$\begin{array}{l}\text { Off treatment } \\
\text { at } 2 \text { years }\end{array}$} & \multicolumn{2}{|c|}{ Androgen Independence } & \multicolumn{2}{|c|}{ Overall Survival } \\
\hline & HR & HR & 95\%c.i. & \\
\hline No & 12.12 & \multirow[t]{2}{*}{$5.93-24.74$} & 2.24 & \multirow[t]{2}{*}{$1.56-3.23$} \\
\hline \multirow[t]{2}{*}{ Yes } & ref & & ref & \\
\hline & \multicolumn{2}{|c|}{$\begin{array}{l}\text { Chi squared }=97.77 \\
P<0.0001\end{array}$} & \multicolumn{2}{|c|}{$\begin{array}{l}\text { Chi squared }=21.49 \\
P<0.0001\end{array}$} \\
\hline \multirow{2}{*}{$\begin{array}{l}{ }^{*} \text { Off } \\
\text { treatment at } \\
2 \text { years }\end{array}$} & \multicolumn{2}{|c|}{ Androgen Independence } & \multicolumn{2}{|c|}{ Overall Survival } \\
\hline & HR & 95\%c.i. & HR & 95\%c.i. \\
\hline No & 9.5 & \multirow[t]{2}{*}{$4.6-19.5$} & 2.2 & \multirow[t]{2}{*}{$1.45-3.2$} \\
\hline \multirow[t]{2}{*}{ Yes } & & & ref & \\
\hline & \multicolumn{2}{|c|}{$\begin{array}{l}\text { Chi squared }=68.33 \\
P<0.0001\end{array}$} & \multicolumn{2}{|c|}{$\begin{array}{l}\text { Chi squared }=15.76 \\
P<0.0001\end{array}$} \\
\hline \multirow{2}{*}{$\begin{array}{l}\text { *Off } \\
\text { treatment at } \\
3 \text { years }\end{array}$} & \multicolumn{2}{|c|}{ Androgen Independence } & \multicolumn{2}{|c|}{ Overall Survival } \\
\hline & HR & 95\%c.i. & HR & 95\%c.i. \\
\hline No & 6.82 & \multirow[t]{2}{*}{$2.96-15.72$} & 2.93 & \multirow{2}{*}{$1.68-5.11$} \\
\hline \multirow{2}{*}{ Yes } & ref & & ref & \\
\hline & \multicolumn{2}{|c|}{$\begin{array}{l}\text { Chi squared = } 34.18 \\
P<0.0001\end{array}$} & \multicolumn{2}{|c|}{$\begin{array}{l}\text { Chi squared }=17.73 \\
P<0.0001\end{array}$} \\
\hline
\end{tabular}

Table 5.

\begin{tabular}{|l|l|l|l|}
\hline \multirow{2}{*}{$\begin{array}{l}\text { Duration of remission } \\
\text { greater than the median for } \\
\text { all patients }\end{array}$} & $\begin{array}{l}\text { PSA level prompting restarting of hormone } \\
\text { therapy }\end{array}$ \\
\cline { 2 - 4 } & $\mathbf{2 1 0}$ & $\mathbf{1 0 - 2 0}$ & $\mathbf{2 0}$ \\
\hline No & 257 & 345 & 45 \\
\hline Yes & 232 & 367 & 41 \\
\hline Total & 489 & 712 & 86 \\
\hline Median for group (months) & 11.6 & 12.3 & 12.0 \\
\hline Pearson, chi $^{2}(\mathbf{2})=\mathbf{2 . 1 0 5 9}$ & $\mathbf{P}=\mathbf{0 . 3 4 9}$ & \multicolumn{2}{|l}{} \\
\hline
\end{tabular}


Appendix 1

\begin{tabular}{|c|c|c|c|c|c|c|c|c|c|c|c|c|c|c|c|c|}
\hline & & \multicolumn{5}{|c|}{ Group 1} & \multicolumn{5}{|c|}{ Group 2} & \multicolumn{5}{|c|}{ Group 3} \\
\hline \multicolumn{2}{|c|}{ Factor } & $\mathbf{n}$ & $\begin{array}{c}\% \\
\text { Off } \\
\text { treatment }\end{array}$ & HR & 95\% c.i. & $\mathbf{P}$ & $\mathbf{n}$ & \begin{tabular}{|c|}
$\%$ \\
Off \\
treatment
\end{tabular} & HR & 95\% c.i. & $\mathbf{P}$ & $\mathbf{n}$ & $\begin{array}{c}\% \\
\text { Off } \\
\text { treatment }\end{array}$ & HR & 95\% c.i. & $\mathbf{P}$ \\
\hline \multirow{3}{*}{ T stage } & 1 or 2 & 251 & 29 & & & \multirow{3}{*}{0.8} & 212 & 37 & & & \multirow{3}{*}{0.0008} & 54 & 47 & & & \multirow{3}{*}{0.9} \\
\hline & 3 or 4 & 187 & 29 & 1.04 & $0.83-1.20$ & & 181 & 25 & 1.48 & $1.18-1.87$ & & 72 & 40 & 1.02 & $0.68-1.54$ & \\
\hline & missing & 37 & 26 & & & & 113 & 42 & & & & 185 & 28 & & & \\
\hline \multirow{4}{*}{ Initial PSA } & $<10$ & 91 & 41 & & & \multirow{4}{*}{$\begin{array}{l}0.0003 \\
\text { (Trend) }\end{array}$} & 175 & 41 & & & \multirow{4}{*}{$\begin{array}{c}0.05 \\
\text { (Trend) }\end{array}$} & 23 & 70 & & & \multirow{4}{*}{$\begin{array}{l}<0.0001 \\
\text { (Trend) }\end{array}$} \\
\hline & $10-75$ & 295 & 25 & 1.47 & $1.11-1.95$ & & 287 & 27 & 1.44 & $1.14-1.92$ & & 163 & 39 & 1.77 & $1.04-3.03$ & \\
\hline & $>75$ & 60 & 23 & 1.41 & $1.16-1.72$ & & 21 & 56 & 0.95 & $0.73-1.24$ & & \begin{tabular}{|l|}
116 \\
\end{tabular} & 20 & 1.66 & $1.26-2.18$ & \\
\hline & missing & 71 & 42 & & & & 23 & 33 & & & & 9 & 33 & & & \\
\hline \multirow{3}{*}{ Gleason grade } & $2-7$ & 165 & 30 & & & \multirow{3}{*}{0.05} & 185 & 38 & & & \multirow{3}{*}{0.008} & 53 & 51 & & & \multirow{3}{*}{0.2} \\
\hline & $>7$ & 237 & 28 & 1.26 & $0.99-1.58$ & & 249 & 29 & 1.36 & $1.08-1.71$ & & \begin{tabular}{|l|}
133 \\
\end{tabular} & 43 & 1.25 & $0.86-1.8$ & \\
\hline & missing & 67 & 29 & & & & 72 & 38 & & & & 125 & 17 & & & \\
\hline \multirow{4}{*}{$\begin{array}{c}\text { Type of } \\
\text { medication }\end{array}$} & antiandrogen & 68 & 11 & 2.14 & $1.23-3.24$ & 0.005 & 77 & 10 & 2.59 & $1.83-3.72$ & 0.0001 & 17 & 0 & 1.16 & $0.88-1.36$ & 0.3 \\
\hline & LHRH & 39 & 31 & 1.2 & $0.96-1.45$ & 0.7 & 93 & 38 & 1.02 & $0.93-1.10$ & 0.9 & 12 & 39 & 1.3 & $0.77-1.82$ & 0.7 \\
\hline & MAB & 404 & 32 & & & & 389 & 38 & & & & 334 & 15 & & & \\
\hline & missing & 0 & - & & & & 6 & 42 & & & & 23 & 26 & & & \\
\hline \multirow{4}{*}{$\begin{array}{l}\text { Duration on } \\
\text { treatment }\end{array}$} & $<4$ months & 148 & 35 & & & \multirow{4}{*}{$\begin{array}{c}0.3 \\
\text { (Trend) }\end{array}$} & 125 & 42 & & & \multirow{4}{*}{$\begin{array}{c}0.08 \\
\text { (Trend) }\end{array}$} & 75 & 32 & 1.35 & $1-1.83$ & \multirow{4}{*}{$\begin{array}{c}0.06 \\
\text { (Trend) }\end{array}$} \\
\hline & 4-8 months & 102 & 24 & 1.26 & $0.93-1.67$ & & 169 & 28 & 1.36 & 1.03-1.81 & & 81 & 27 & 1.17 & $1-1.82$ & \\
\hline & $>8$ months & 219 & 27 & 1.06 & $0.88-1.45$ & & 211 & 32 & 1.1 & $0.93-1.60$ & & \begin{tabular}{|l|}
151 \\
\end{tabular} & 39 & & & \\
\hline & missing & 0 & - & & & & 1 & 100 & & & & 1 & 0 & & & \\
\hline \multirow{4}{*}{ PSA nadir } & $<1$ & 273 & 33 & & & \multirow{4}{*}{$\begin{array}{c}0.003 \\
\text { (Trend) }\end{array}$} & 395 & 35 & & & \multirow{4}{*}{$\begin{array}{c}0.049 \\
\text { (Trend) }\end{array}$} & 180 & 41 & & & \\
\hline & $1-2$ & 67 & 15 & 1.68 & $1.24-2.28$ & & 32 & 40 & 0.85 & $0.53-1.35$ & & 30 & 23 & 1.36 & $0.89-2.08$ & (Trend) \\
\hline & $>2$ & 29 & 30 & 1.45 & $0.92-2.27$ & & 18 & 8 & 3.63 & $1.75-7.53$ & & 49 & 21 & 1.43 & $1.20-1.71$ & \\
\hline & missing & 100 & 25 & & & & 61 & 25 & & & & 32 & 31 & & & \\
\hline & $\leq 65$ & 70 & 23 & 1.16 & $0.88-1.56$ & & 145 & 25 & 1.55 & $1.25-1.94$ & & 102 & 29 & 1.19 & $0.91-1.55$ & \\
\hline Age & $>65$ & 393 & 30 & & & 0.3 & 353 & 37 & & & 0.0001 & 200 & 38 & & & 0.2 \\
\hline & missing & 6 & 42 & & & & 8 & 43 & & & & 9 & 11 & & & \\
\hline & none & - & - & - & - & & - & - & - & - & & 281 & 31 & 2.2 & $1.39-3.48$ & \\
\hline $\begin{array}{l}\text { Previous } \\
\text { treatment }\end{array}$ & RP and/or RT & - & - & - & - & - & - & - & - & - & - & 30 & 57 & & & 0.0002 \\
\hline & missing & - & - & - & - & & - & - & - & - & & - & - & - & - & \\
\hline & $\leq 15$ & 190 & 29 & 1.03 & $0.82-1.28$ & & 236 & 30 & 1.12 & $0.91-1.38$ & & 85 & 32 & & & \\
\hline PSA restart & $>15$ & 294 & 28 & & & 0.8 & 280 & 35 & & & 0.3 & \begin{tabular}{|l|}
271 \\
\end{tabular} & 33 & 1.1 & $0.83-1.46$ & 0.5 \\
\hline & missing & 33 & 33 & & & & 42 & 47 & & & & 10 & 27 & & & \\
\hline
\end{tabular}




\begin{tabular}{|c|c|c|c|c|c|c|c|c|c|c|}
\hline \multicolumn{7}{|c|}{ Androgen Independence } & dence & & & \\
\hline \multirow{2}{*}{\multicolumn{2}{|c|}{ Factor }} & Group 1 & Group 2 & Group 3 & Group 1 & Group 2 & Group 3 & Group 1 & Group 2 & Group 3 \\
\hline & & HR $\left(\mathrm{chi}^{2}\right)$ & $\operatorname{HR}\left(\mathrm{chi}^{2}\right)$ & HR $\left(\mathrm{chi}^{2}\right)$ & HR $\left(\mathrm{chi}^{2}\right)$ & $\mathrm{HR}\left(\mathrm{chi}^{2}\right)$ & HR $\left(\mathrm{chi}^{2}\right)$ & HR $\left(c^{2} i^{2}\right)$ & HR $\left(\mathrm{chi}^{2}\right)$ & $\operatorname{HR}\left(\mathrm{chi}^{2}\right)$ \\
\hline \multirow{2}{*}{ T stage } & $1-2$ & \multirow{2}{*}{ NS } & Ref & \multirow{2}{*}{ NS } & \multirow{2}{*}{ NS } & \multirow{2}{*}{ NS } & \multirow{2}{*}{ NS } & Ref & \multirow{2}{*}{ NS } & \multirow{2}{*}{ NS } \\
\hline & $3-4$ & & $1.48(11.34) * * *$ & & & & & $1.85(3.31)^{\star *}$ & & \\
\hline \multirow{3}{*}{ Initial PSA } & $<10$ & Ref & Ref & Ref & Ref & Ref & Ref & Ref & \multirow{3}{*}{ NS } & Ref \\
\hline & $10-75$ & $1.47(7.8)$ ** & $1.44(9.9)$ *** & $1.77(5.06)^{\star \star}$ & $6.42(5.55)^{\star \star \star}$ & $1.62(2.4)^{*}$ & $5.52(5.09)^{\star *}$ & $2.70(4.21)^{\star \star}$ & & NS \\
\hline & $>75$ & $1.41(11.15)^{\star \star *}$ & NS & $1.66(16.12)^{\star \star \star *}$ & $2.65(3.96)^{\star *}$ & NS & $3.26(5.23)^{\star *}$ & NS & & $2.33(9.42)^{\star \star \star}$ \\
\hline \multirow{2}{*}{\begin{tabular}{|l|} 
Gleason \\
grade
\end{tabular}} & $\leq 7$ & \multirow{2}{*}{ NS } & Ref & \multirow{2}{*}{ NS } & \multirow{2}{*}{ NS } & \multirow{2}{*}{ NS } & \multirow{2}{*}{ NS } & \multirow{2}{*}{ NS } & \multirow{2}{*}{ NS } & \multirow{2}{*}{ NS } \\
\hline & $>7$ & & $1.36(7.15)^{\star \star}$ & & & & & & & \\
\hline \multirow{3}{*}{$\begin{array}{l}\text { Type of } \\
\text { medication }\end{array}$} & MAB & Ref & Ref & \multirow{3}{*}{ NS } & Ref & \multirow{3}{*}{ NS } & \multirow{3}{*}{ NS } & \multirow{3}{*}{ NS } & $2.28(6.12)^{*}$ & \multirow{3}{*}{ NS } \\
\hline & LHRH alone & NS & NS & & 4.41 (5.82)* $^{*}$ & & & & $4.28(13.68)^{\star \star \star}$ & \\
\hline & antiandrogen & $2.14(19.11)^{* \star *}$ & $2.59(39.31)^{\star \star \star}$ & & \begin{tabular}{|l|}
$3.78(4.84)^{*}$ \\
\end{tabular} & & & & Ref & \\
\hline \multirow{3}{*}{$\begin{array}{l}\text { Duration of } \\
\text { treatment }\end{array}$} & $\leq 4$ months & \multirow{3}{*}{ NS } & \multirow{3}{*}{ NS } & \multirow{3}{*}{ NS } & Ref & \multirow{3}{*}{ NS } & & & & $1.86(2.89)^{*}$ \\
\hline & 4-8 months & & & & $4.44(2.4)^{*}$ & & NS & NS & NS & $2.83(13.54)^{\star \star \star \star}$ \\
\hline & $\geq 8$ months & & & & $6.05(5.1)^{* *}$ & & & & & Ref \\
\hline & $<1$ & Ref & Ref & Ref & & & Ref & & & Ref \\
\hline PSA nadir & $1-2$ & $1.68(10.87)^{\star \star *}$ & NS & NS & NS & NS & $2.12(6.98)^{\star *}$ & NS & NS & $2.12(6.98)^{\star \star}$ \\
\hline & $>2$ & NS & $1.77(10.69)^{* \star \star}$ & $1.43(13.86)^{\star \star \star}$ & & & NS & & & NS \\
\hline Aqe & $<65$ & & $1.55(14.55)^{\star \star \star}$ & & & & & & & \\
\hline Age & $\geq 65$ & NS & Ref & NS & NS & NS & NS & NS & NS & NS \\
\hline \begin{tabular}{|l|}
$\begin{array}{l}\text { Previous } \\
\text { treatment }\end{array}$ \\
\end{tabular} & \begin{tabular}{|l|} 
none \\
RP \&/or RT \\
\end{tabular} & N/A & N/A & \begin{tabular}{|c|} 
Ref \\
$2.2(14.04)^{\star \star \star}$ \\
\end{tabular} & N/A & N/A & NS & N/A & N/A & NS \\
\hline PSA restart & $\leq 15$ & NS & NS & NS & NS & NS & Ref & NS & NS & Ref \\
\hline threshold & $>15$ & NS & NS & INS & NS & NS & $1.33(4.11)^{*}$ & NS & NS & $1.65(4.08)^{*}$ \\
\hline
\end{tabular}


Appendix 3

\begin{tabular}{|c|c|c|c|}
\hline & $\mathbf{N}$ & $\mathrm{Chi}^{2}$ & Change Chi ${ }^{2}$ \\
\hline \multicolumn{4}{|c|}{ Group 1- Time off treatment } \\
\hline $\mathrm{IP}$ & 446 & 9.67 & 9.67 \\
\hline $\mathrm{IP}+\mathrm{IPm}$ & 464 & 12.31 & \\
\hline$I P+I P m+M A B$ & 464 & 29.92 & 17.61 \\
\hline $\mathrm{IP}+\mathrm{IPm}+\mathrm{MAB}+\mathrm{MABm}$ & 369 & 37.5 & \\
\hline $\mathrm{IP}+\mathrm{IPm}+\mathrm{MAB}+\mathrm{MABm}+\mathrm{PN}$ & 369 & 46.95 & 9.45 \\
\hline $\mathrm{IP}+\mathrm{IPm}+\mathrm{MAB}+\mathrm{MABm}+\mathrm{PN}+\mathrm{PNm}$ & 402 & 38.84 & \\
\hline $\mathrm{IP}+\mathrm{IPm}+\mathrm{MAB}+\mathrm{MABm}+\mathrm{PN}+\mathrm{PNm}+\mathrm{G}$ & 402 & 46.05 & 7.21 \\
\hline \multicolumn{4}{|c|}{ Group 2- Time off treatment } \\
\hline MAB & 501 & 13.98 & 13.98 \\
\hline$M A B+M A B m$ & 497 & 14.58 & \\
\hline$M A B+M A B m+A$ & 497 & 29.06 & 14.48 \\
\hline$M A B+M A B m+A+A m$ & 482 & 25.09 & \\
\hline $\mathrm{MAB}+\mathrm{MABm}+\mathrm{A}+\mathrm{Am}+\mathrm{IP}$ & 482 & 31.46 & 6.37 \\
\hline \multicolumn{4}{|c|}{ Group 3- Time off treatment } \\
\hline IP & 302 & 23.86 & 23.86 \\
\hline $\mathrm{IP}+\mathrm{IPm}$ & 311 & 23.89 & \\
\hline IP+IPm+PrevRx & 311 & 35.6 & 11.71 \\
\hline \multirow{2}{*}{ IP+IPm+PrevRx +PN } & 259 & 39.05 & 4.55 \\
\hline & $\mathrm{N}$ & $\mathrm{Chi}^{2}$ & Change $\mathrm{Chi}^{2}$ \\
\hline \multicolumn{4}{|c|}{ Group 3- Androgen Independence } \\
\hline IP & 355 & 24.48 & 24.48 \\
\hline $\mathrm{IP}+\mathrm{IPm}$ & 346 & 27.23 & \\
\hline \multirow[t]{2}{*}{$\mathrm{IP}+\mathrm{IPm}+\mathrm{RT}$} & 346 & 30.07 & 5.59 \\
\hline & $\mathrm{N}$ & $\mathrm{Chi}^{2}$ & Change $\mathrm{Chi}^{2}$ \\
\hline \multicolumn{4}{|c|}{ Group 3- Overall Survival } \\
\hline $\mathrm{ON}$ & 329 & 13.72 & 13.72 \\
\hline $\mathrm{ON}+\mathrm{ONm}$ & 280 & 10.39 & \\
\hline $\mathrm{ON}+\mathrm{ONm}+\mathrm{PN}$ & 280 & 17.09 & 3.37 \\
\hline $\mathrm{ON}+\mathrm{ONm}+\mathrm{PN}+\mathrm{PNm}$ & 277 & 17.04 & \\
\hline $\mathrm{ON}+\mathrm{ONm}+\mathrm{PN}+\mathrm{PNm}+\mathrm{IP}$ & 277 & 23.27 & 6.18 \\
\hline $\mathrm{ON}+\mathrm{ONm}+\mathrm{PN}+\mathrm{PNm}+\mathrm{IP}+\mathrm{IPm}$ & 275 & 24.86 & \\
\hline $\mathrm{ON}+\mathrm{ONm}+\mathrm{PN}+\mathrm{PNm}+\mathrm{IP}+\mathrm{IPm}+\mathrm{MAB}$ & 275 & 30.42 & 7.15 \\
\hline $\mathrm{ON}+\mathrm{ONm}+\mathrm{PN}+\mathrm{PNm}+\mathrm{IP}+\mathrm{IPm}+\mathrm{MAB}+\mathrm{MABm}$ & 267 & 28.16 & \\
\hline $\mathrm{ON}+\mathrm{ONm}+\mathrm{PN}+\mathrm{PNm}+\mathrm{IP}+\mathrm{IPm}+\mathrm{MAB}+\mathrm{MABm}+\mathrm{RT}$ & 267 & 37.03 & 6.61 \\
\hline
\end{tabular}


Table 1. Showing the origins, characteristics and basic protocol for IHT from the different contributing authors.

$(\mathrm{L}=$ localized disease primary treatment, $\mathrm{R}=$ biochemical recurrence after RP/RT localized , A= advanced disease)

Table 2. Overall survival, time off treatment and time to developing AIPC for all patients by group.

Table 3. Summary of risk factors as predictors of outcome in univariate analysis by group.

Figure 1a and 1b. Kaplan Meier survival analysis to show the overall survival by group and the effect of Initial PSA on the duration of remission in patients with localised disease treated primarily with hormone therapy (group 1)

Figure 2. Graphs to demonstrate the relative contributions of individual factors in multivariate models predicting treatment outcomes.

Table 4. Time off Rx as a surrogate measure for AIPC and overall survival. (For data marked *, In order to avoid a length time bias those patients who have neither been off treatment for the duration of interest- 2 or 3 years, or restarted treatment are excluded).

Table 5. Analysis of association between duration of preceeding remission and PSA threshold at which treatment is restarted.

Appendices

Appendix 1. Univariate analysis of risk factors for being off treatment at 2 years (group 1 and 2) or 1 year (group 3)

Appendix 2. Significance of factors predicting time off treatment in the different clinical groups by univariate analysis $\left({ }^{*}=p<0.05,{ }^{* *}=p<0.01,{ }^{* *}=p<0.001\right)$

Appendix 3. Multivariate model for each group predicting duration of remission (time off treatment) based on initial PSA (IP), PSA nadir $<1$ (PN) reached, type of hormone therapy (MABvs monotherapy), tumour gleason grade(G), T stage (T), Age (A), Previous treatment (PrevRx), Restart PSA Threshold (RT) 